\title{
Impact of Technological Innovation on Product and Distribution Strategies in Mobile Phone Industry
}

\author{
Sunny Dawar ${ }^{1}$, Prince Dawar ${ }^{2}$, Pallavi Kudal ${ }^{3}$ \\ ${ }^{1}$ Manipal University Jaipur, Rajasthan, India, sunny.dawar86@gmail.com \\ ${ }^{2}$ Poornima Group of Colleges, Rajasthan, India, dawarprince83@gmail.com \\ ${ }^{3}$ Dr DY Patil Institute of Management Studies, Pune, Maharashtra, India ,pallavikudal@gmail.com
}

\begin{abstract}
Technological innovation is considered to be an important driver of productivity growth. It also influences the marketing in numerous ways. To promote and sales of the products, there are many ways in which technological innovation influences creating innovative products on reasonable prices with advanced virtual platforms. The mobile phone industry undoubtedly has evolved over time with an enormous speed in all the manufacturing industries based on technology. The study has been done with the objective to discover the impact of technological innovation on product and distribution strategies in mobile phone industry. The research has been done using empirical research design. The study found that there is positive and significant impact of level of technological innovation used in mobile phone industry on product and distribution strategies.
\end{abstract}

Keywords: Technological innovation, Product strategies, Distribution strategies, Virtual platform

\section{INTRODUCTION}

Every business has to create the customer base to build the market so as to survive and ensure growth in the market. The business enterprise has to perform two functions namely innovation and marketing. Innovation is considered primary source to gain competitive advantage [1]. Marketing strategy allows companies to innovate for providing satisfaction more effectively in comparison to competitors [2].

There is a common concept that firm should enhance innovation so as to maintain competitive strength in the target market for effectively including innovative promotion strategy to incorporate firm's overall strategic framework. Contemporary research has proved that mobile telephony has become beneficial in many ways to provide advantages using the technology in many industries. The common advantages of mobile telephony in relations to different communication systems requires less all-round infrastructure facilities to work than available mobile networks. There is an exponential increase in the services diversities, area coverage and financial investments of mobile phone technology.

Mobile technology has become biggest driver responsible of economic growth of any county. The growth of Indian mobile phone industry has witnessed of tremendous growth since its origin. Mobile phones are regarded as more valuable than any other available communication device and this is supporting convergence of technologies and other devices enormously in the growth at social, economic, and technological level. The technological innovation is providing support in the expansion of mobile phone industry.

Technological innovation is known as advancement through which innovative technical features are prolonged and brought into broad applications in technical devices and instruments. Innovation is a constant process which is initiated by the perception of new market and new services benefits are created by the technology which has led the production, growth, and marketing functions to strive for the commercial achievements due to inventio [3]. Usually, innovation is not considered as linear system; it includes many interconnections and responses feedback in all expansion stages. The technological innovation has completely modified from a singular innovation project to an effective and accessible innovation system [4]. There has been increase in the importance of networks and collaborations of technical advancements $[5,6]$.

\section{LITERATURE REVIEW}

The technological innovations include a series of scientific, commercial, organizational, financial, and technical activities [7]. Before submission of a technology in commercial purpose, there requires so many advancements and innovations [8]. Complementary resources are crucial to beat the competition level which decides the firm's business strategy for sourcing and fulfilment of complementary assets [9]. Technological innovation not only playing a keen role in the improvement of firms' performance [10]but also functions as an important competitive technique [11]. Innovation has six types ofnamely innovative products, services, production methods, new markets, supply sources and innovative ways of organising [12].Innovation objects create organization for the growth of products and services for serving the customers [13]. Technological innovation is classified as radical and incremental innovation and comprises the scope from sustainable innovation to disruptive innovation [14]. 
Radical innovation involves all significant innovative technologies which requires necessary changes in consumption avenues and are regarded as an offer to increase the benefits. There are many firms related to market which may try themselves to extensively use of incremental innovation related to modifications of existing technical and designs that is called dominant design. Many empirical studies had shown that products attributes have effect on the growing patterns of products and services [15].

Innovation depends on characteristics of products and how does it influence the rate of adoption of technical capabilities [16]. There are many characteristics of innovation consisting relative advantages, complexity and compatibilities which encourage customers of mobile marketing acceptance [17]. Innovation comprises both technological like innovative products, services and administrative innovation related to new procedures, polices. The main significant factor related to successful business strategy and an essential element which have affect the marketing process [18]. Sharing of global information has enhanced the firm's competence and assisted in meeting the customers need to modify an international organization into a famous global firm[19].

Technological convergence has evolved the telecom industry in modifying the mobile phones and altered the digital marketplace and has given birth to next generation mobile phones [20]. Markets are transferring to intensive research for knowing the customer's buying decision process and found the most essential factors having direct influence on customers' choices in the mobile phone market [21]. [22] described the relationship between firms' value and new product development in the mobile handset manufacturing from 1992-2002. Radical and incremental innovations enhance the firm's market share if they adopt the new product development in mobile industry. Mobile phone adopts the innovative marketing strategies so as to provide great facilities and comfort to consumers [23].

The conventional ecosystems have controlled the mobile operators and handsets producers which have diversified the demands of mobile handsets in the markets all around the world and increasing the growth pattern of mobile telecommunication [24]. Innovation have capabilities to affect the different dimensions of personalities of customers which may control the buying decision and customer buying behavior[25]. There are direct effects of rate of innovation introduction on product component, design, and innovative platforms for selling and distributing the mobile handsets [26]. Technological advancements have completely changed the patterns in which a customer acts and obtains information to communicate the other people by which marketing of firms have been completely changed[27].

Consumers' perception for using the high technologically developed products is determined by the extrinsic and intrinsic motivations [28]. Customer's switching behavior depends on various push factors like satisfaction and value in the mobile phone marketwhich determine the growth patterns and overall satisfaction in the [29]. Consumption of mobile phone has increased the demand of mobile handsets in the market which ultimately has brought the trend quicker and personalized the public communication supporting the new facet of virtual mobility in the Indian mobile phone market. Consumer innovativeness, perceived usefulness and personal attachments have directly influenced the customer attitude for mobile marketing. The research belongs to high innovation category form positive attitudes in the mobile marketing areas in the application of virtual programme by engaging the consumers in different innovative platforms [30].

Innovative technology is radically modifying the approach which companies target the market and help web-based marketing techniques [31]. Strategic capabilities facilitate the influence of technology on firm's performance in new ventures [32]. The technological innovation capabilities directly influence the product competitiveness of Chinese production firms and recognize the key components of technical innovations [33].

There are two variables which have direct influence on variables which affect the buying through mobile advertising. First variable is the customer's attitude for mobile advertising which show significant positive effects on buying using mobile advertising. Second variable is social factor which have a good response on mobile advertising and a have high social effect on mobile advertising[34]. It was demonstrated to measure the user's productivity through mapping the design implication of process related to cognition for the user interface of application. The output of this mapping was to set the guidelines which support the designer using the designing the mobile application in diverting environment [35].

\section{RESEARCH METHODOLOGY}

The study adopted the empirical research design to work upon the research problem and anintended questionnaire was applied to collect data to testhypotheses framed established on the analysis of literature. The study collected data from companies' executives and officers working in mobile phone companies on different designationsA survey response of 195 was taken in Rajasthan and Delhi and for testing the research constructs and data was analysed using SPSS 20.0. The research utilized five-point rating levelvarying from strongly disagree to strongly agree. The online and personal survey was conducted and after doing comprehensive data cleaning, 195 responses were considered for the analysis.

\subsection{Hypotheses}

$\mathrm{H}_{1}$ : There is a significant and positive impact of technological innovation product strategies.

$\mathrm{H}_{2}$ : There is a significant and positive impact of technological innovation on distribution strategies.

\section{DATA ANALYSIS AND INTERPRETATION}

\subsection{Reliability Analysis}

This analysis was conducted through the use of Cronbach's alpha to analyse the internal consistency among various research items utilized in the 
questionnaire for the study. The research items which did not fulfil the internal consistency of reliability analysis, they were removed.Below table no. 1 shows reliability analysis.

Table 1: Analysis of Reliability

\begin{tabular}{|c|c|}
\hline \multicolumn{2}{|c|}{ Reliability Statistics } \\
\hline Value of Cronbach Alpha & Number of Items \\
.966 & 30 \\
\hline
\end{tabular}

\subsection{Level of Value Addition by Technological Innovation to Different Aspects of Business}

Following figure 1 shows that technological innovation plays a significant role in the improvement of overall performance of the business and helps to gain the competitive advantages to the company.

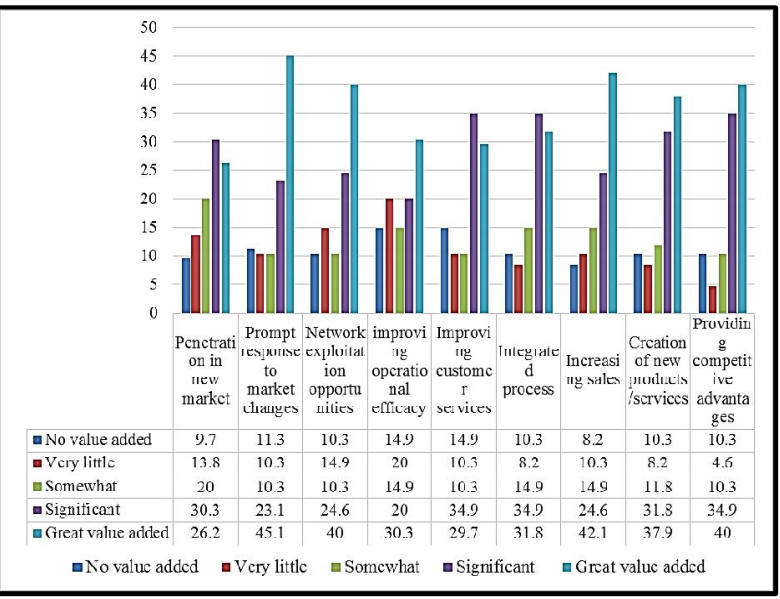

Figure 1: Technological Innovation and Business Aspects

\subsection{Normality of Data}

Two different tests of normality, first KolmogorovSmirnov and Shapiro-Wilk test were conducted to check the normality. Both the tests compared the shape of the sample distribution using the shape of normal bell-shaped curve.

As per below mentioned table no. 2, it is clear that collected data shows that factors related to product and distribution shows significance value (p) .000. As the significant value ( $\mathrm{p}$-value) is less than 0.05 then null hypothesis is rejected and the alternative hypothesis is accepted for the non-normal fashion of data.
Table 2: Tests of Normality

\begin{tabular}{|l|c|c|c|c|c|c|}
\hline \multirow{3}{*}{ Items } & \multicolumn{3}{|c|}{$\begin{array}{c}\text { Kolmogorov- } \\
\text { Smirnov }\end{array}$} & \multicolumn{3}{c|}{ Shapiro-Wilk } \\
\cline { 2 - 7 } & $\begin{array}{c}\text { Stat } \\
\text { istic }\end{array}$ & df & Sig. & $\begin{array}{c}\text { Stati } \\
\text { stic }\end{array}$ & df & Sig. \\
\hline Product & .190 & 195 & .000 & .868 & 195 & .000 \\
\hline $\begin{array}{l}\text { Distribution( } \\
\text { Place) }\end{array}$ & .172 & 195 & .000 & .879 & 195 & .000 \\
\hline
\end{tabular}

\subsection{Correlation Analysis:}

Correlation analysis was conducted to find out the correlation among different variables used to conduct the study. This analysis represented the complex web of associations among variables. Kenall's Tau Correlation was calculated to analysis of series of variables. This coefficient analysis indicated a positive association among different factors. As it is clear in table no. 3 , the value comes in green cells are less than 0.05 which shows that that correlation is statistically significant.

Table 3: Correlation Analysis

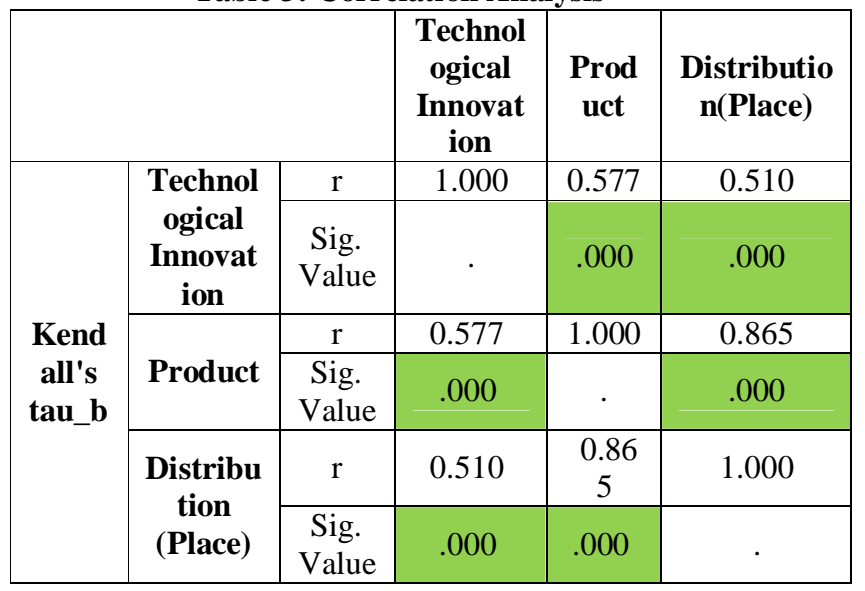

\subsection{Hypotheses Testing}

$H_{1}$ : There is a significant and positive impact of technological innovation product strategies.

To test the above hypothesis linear regression analysis was conducted. Results of the analysis are exhibited in thefollowing table no. 4 related to effect of technological innovation and product strategies. This analysis was done atthe significance level of 0.05 .

Table 4: Summary of model for Regression Analysis

\begin{tabular}{|c|c|c|c|c|}
\hline $\mathbf{R}$ & $\begin{array}{c}\mathbf{R} \\
\text { Square }\end{array}$ & $\begin{array}{c}\text { Adjusted } \\
\mathbf{R} \\
\text { Square }\end{array}$ & $\begin{array}{c}\text { Std. } \\
\text { Error of } \\
\text { the } \\
\text { Estimate }\end{array}$ & $\begin{array}{c}\text { Durbin- } \\
\text { Watson }\end{array}$ \\
\hline .597 & .357 & .352 & 1.35069 & 1.536 \\
\hline \multicolumn{4}{|l}{ Predictors: (Constant), Technological Innovation } \\
\hline \multicolumn{4}{|l}{ Dependent Variable: Product } \\
\hline
\end{tabular}


The $\mathrm{R}$ value in table 4 shows bivariate correlation between technological innovation and product is .597. The Rsquare value was found .357 or $35.7 \%$ and the adjusted $\mathrm{R}$ square was found $.352 .35 .2 \%$ variation was explained by the technological innovation into product. Durbin Watson value was found 1.536 which is in between -2 and +2 that proves that there is no auto correlation in technological innovation and product.

Table 5 : Results of ANOVA of Regression Analysis

\begin{tabular}{|l|c|c|c|c|c|}
\hline \multicolumn{7}{|c|}{ ANOVA } \\
\hline & $\begin{array}{c}\text { Sum of } \\
\text { Squares }\end{array}$ & Df & $\begin{array}{c}\text { Mean } \\
\text { Square }\end{array}$ & F & Sig. \\
\hline Regression & 24.923 & 1 & 24.923 & 13.661 & .000 \\
\hline Residual & 352.104 & 193 & 1.824 & & \\
\hline Total & 377.027 & 194 & & & \\
\hline Predictors: (Constant), Technological Innovation \\
\hline Dependent Variable: Product \\
\hline
\end{tabular}

The impact of technological innovation on product strategies was found significantly fit $(\mathrm{p}<.05)$ as shown in the ANOVA table 5 due to $F(1,193)=13.661$ and significance value is .000 . The relationship deemed to be linear as computed significance level is .000 which is less than the anticipated level (Significance level 0.05).

Table 6: Significance Test

\begin{tabular}{|l|c|c|c|c|}
\hline & \multicolumn{2}{|c|}{$\begin{array}{c}\text { Unstandardized } \\
\text { Coefficients }\end{array}$} & t & \multirow{2}{*}{ Sig. } \\
\cline { 2 - 3 } & B & $\begin{array}{c}\text { Std. } \\
\text { Error }\end{array}$ & & \\
\hline (Constant) & 2.655 & .242 & 10.976 & .000 \\
\hline $\begin{array}{l}\text { Technological } \\
\text { Innovation }\end{array}$ & .246 & .067 & 3.696 & .000 \\
\hline Predictors: (Con & & & \\
\hline
\end{tabular}

Predictors: (Constant), Technological Innovation

Dependent Variable: Product

As per above table no. 6, the coefficient of technological innovation was found significantly effecting the product. The magnitude of this coefficient was found .246. The significance value was found .000 which is less than .05 then the variable deemed to be significant.

Equation after the application of regression model;

$$
\mathrm{Y}(\text { product })=2.655+.246(\text { technological innovation })
$$

The technological innovation is positively associated with the product as per the result of regression model. The regression coefficient is .246. The significance level .000 $(p<0.05)$ indicates that regression co-efficient is statistically significant and the factor significantly contributes in the variations of dependent variable i.e. product. So that null hypothesis is not accepted, and alternate hypothesis is accepted i.e. there is a positive and significant impact of technological innovation on product strategies.
$\mathrm{H}_{2:}$ There is a significant and positive impact of technological innovation on distribution strategies.

To test the above hypothesis linear regression analysis was conducted. The results of the analysis are shown in the following table no.7 related to effect of technological innovation and product. This analysis was done at the significance level of 0.05 .

Table7 : Model Summary for Regression Analysis

\begin{tabular}{|c|c|c|c|c|}
\hline $\mathbf{R}$ & $\begin{array}{c}\text { R } \\
\text { Square }\end{array}$ & $\begin{array}{c}\text { Adjusted } \\
\text { R Square }\end{array}$ & $\begin{array}{c}\text { Std. Error } \\
\text { of the } \\
\text { Estimate }\end{array}$ & $\begin{array}{c}\text { Durbin- } \\
\text { Watson }\end{array}$ \\
\hline .530 & .262 & .257 & 1.36406 & 1.549 \\
\hline \multicolumn{4}{|l|}{ Predictors: (Constant), Technological Innovation } \\
\hline
\end{tabular}

The $\mathrm{R}$ value in table 7 shows bivariate correlation between technological innovation and place (distribution) is .530. The $\mathrm{R}$ square value was found .262 or $26.2 \%$ and the adjusted $\mathrm{R}$ square was found $.257 .25 .7 \%$ variation was explained by the technological innovation into the distribution. Durbin Watson value was found 1.549 which is in between -2 and +2 explains that there is no auto correlation in technological innovation and distribution.

Table 8: ANOVA Results for Regression Analysis

\begin{tabular}{|c|c|c|c|c|c|}
\hline \multicolumn{6}{|c|}{ ANOVA } \\
\hline & $\begin{array}{c}\text { Sum of } \\
\text { Squares }\end{array}$ & df & $\begin{array}{c}\text { Mean } \\
\text { Square }\end{array}$ & $\mathbf{F}$ & Sig. \\
\hline Regression & 19.200 & 1 & 19.200 & 10.319 & .002 \\
\hline Residual & 359.105 & 193 & 1.861 & & \\
\hline Total & 378.305 & 194 & & & \\
\hline \multicolumn{6}{|c|}{ Predictors: (Constant), Technological Innovation } \\
\hline \multicolumn{6}{|c|}{ Dependent Variable: Distribution (Place) } \\
\hline \multicolumn{6}{|c|}{$\begin{array}{l}\text { The impact of technological innovation on } \\
\text { distribution was found significantly fit }(\mathrm{p}<.05) \text { as shown in } \\
\text { the ANOVA table } 8 \text { due to } F(1,193)=10.319 \text { and } \\
\text { significance value is .002. The relationship deemed to be } \\
\text { linear as calculated significance level is } .002 \text { which is less } \\
\text { than the desired level (Significance level } 0.05) \text {. }\end{array}$} \\
\hline
\end{tabular}

Table 9 : Significance Test

\begin{tabular}{|l|c|c|c|c|}
\hline \multirow{2}{*}{} & \multicolumn{2}{|c|}{$\begin{array}{c}\text { Unstandardized } \\
\text { Coefficients }\end{array}$} & t & \multirow{2}{*}{ Sig. } \\
\cline { 2 - 4 } & B & $\begin{array}{c}\text { Std. } \\
\text { Error }\end{array}$ & & \\
\hline (Constant) & 2.669 & .244 & 10.923 & .000 \\
\hline $\begin{array}{l}\text { Technological } \\
\text { Innovation }\end{array}$ & .216 & .067 & 3.212 & .002 \\
\hline Predictors: (Constant), Technological Innovation \\
\hline \multicolumn{2}{|l|}{ Dependent Variable: Distribution(Place) } \\
\hline
\end{tabular}

As per above table no. 9, the coefficient of technological innovation was found significant effecting positively the distribution. The magnitude of this coefficient was found .216. The significance value was 
found .002 which is less than .05 then the variable deemed to be significant.

Equation after the application of regression model.

$\mathrm{Y}($ distribution $)=2.669+.216($ technological innovation $)$

The technological innovation is positively associated with the distribution as per the result of regression model. The regression coefficient is .216. The significance level $.002(\mathrm{p}<0.05)$ suggests that regression co-efficient is statistically substantial and the factor significantly contributes to the variations of dependent variable i.e.place (distribution). So null hypothesis is not accepted, and alternate hypothesis is accepted which states that there is a significant and positive impact of technological innovation on distribution (place) strategies.

\section{CONCLUSION}

The companies have to introduce several product innovations for stimulating demand for the additional purchases. The pace of innovative product innovations requires continually restructured the scope of product over the time being. It has been observed that introduction of several revolutionary product technologies has given birth to smartphone devices. With regard to significant impact of technological innovation on product strategies, the results have shown the positive response of technological innovation. Technological innovation comprising product and process innovations have changed the mobile phone from a simple communication device to a multitasking converging product. The rising demand for the technologically converged product known as smartphone. Increasing number of consumer segments have forced the companies to expand their product portfolio with innovative models and also to transform their manufacturing process for the enhancement of product quality.

With regard to the impact of technological innovation on distributions strategies, responses have shown the positive findings. The technological innovation has changed the traditional dimensions of distribution into the digital. The place of physical store has been taken by the virtual stores which have enabled the companies to deliver the product to consumer more rapidly. For the efficient inbound logistics system, the organizations are using computerized scanning systems to inform the suppliers to get the supplies on time. More recent developments in electronic technologies are further improving the efficiency and effectiveness with which the logistical activities are managed and implemented. The accuracy and speedy billing and invoicing customers have become vital important for better customer relationships so that automated emails enabled by the innovative technologies to customers have initiated the online purchase.

\section{REFERENCES}

1. G.S. Day \& R. Wensley. Assessing advantage: a framework for diagnosing competitive superiority, Journal of marketing, Vol. 52, no. 2, pp.1-20, 1988.
2. J. Hauser, G.J. Tellis\& A. Griffin. Research on innovation: A review and agenda for marketing science, Marketing science, vol.25, no. 6, pp. 687717, 2006.

3. OECD. Managing National Innovation Systems, OECD, Paris, 1991

4. H. Chesbrough. The logic of open innovation: managing intellectual property, California Management Review, vol. 45, no. 3,pp. 33-58, 2003.

5. M.A. Casumano. Diversity and innovation in Japanese technology management, Research on Technological Innovation, Management and Policy, vol. 3, pp. 137-167, 1986.

6. K. Viljamma, Technological and cultural challenges in local innovation support activities - emerging knowledge interactions in charlotte's motor support cluster, European Planning Studies, vol. 15, no. 9, pp. 1215-1232, 2007.

7. G. Sirilli\& R. Evangelista. Technological innovation in services and manufacturing: results from Italian surveys, Research Policy, vol. 27, pp. 881-899, 1998.

8. A.H. Van de Van \& R. Garud. A Framework for understanding the emergence of new industries, Research on Technological Innovation, Management and Policy, vol. 4, pp. 153-193, 1989.

9. R. Basant. Analyzing Technology Strategy: Some Issues. Economic and Political Weekly, vol. 32, no. 48, pp.111-120, 1997.

10. J. Tidd. Innovation management in context: Environment, organization and performance,International Journal of Management Reviews, vol.3, no. 3, pp.169-183, 2001.

11. M.T. Flaherty. Market share, technology leadership, and competition in international semiconductor markets. In R. S. Rosenbloom and R.A. Burgelman (eds.). Research on Technological Innovation, Management and Policy, vol. 1, pp. 69102, 1983.

12. J.A. Johannessen, B. Olsen and G.T. Lumpkin. (2001). Innovation as newness: what is new, how new, and new to whom?,European Journal of Innovation Management. vol. 4, no. 1, pp. 20-31, 2001.

13. M. Assink. Inhibitors of disruptive innovation capability: a conceptual model, European Journal of Innovation Management, vol. 9, no. 2, pp. 215-233, 2006.

14. P.A. Abetti. Critical Success Factors for Radical Technological Innovation: A Five Case Study, Creativity and Innovation Management, vol. 9, no. 4, pp.208-221, 2000.

15. R. Peres, V. Mahajan, and E. Muller. Innovation Diffusion and New Product Growth: A Critical Review and Research Directions, International Journal of Research in Marketing, vol. 27, pp. 91106, 2010.

16. M. Wright, \& D. Charlett. New product diffusion models in marketing: an assessment of two approaches, Marketing Bulletin, vol. 6, no. 4, pp.3241, 1995.

17. L.G. Tornatzky\& K. J. Klein. Innovation characteristics and innovation adoptionimplementation: A meta-analysis of findings, IEEE 
Transactions on engineering management, vo. 1, pp. 28-45, 1982.

18. J. Chapman \& C. Holtman. IT in marketing. England. Alfred Waller Ltd, 1994.

19. B. Ives \& S.L. Jarvenpaa. The global network organization of the future: information management opportunities and challenges. Journal of ManagementInformation Systems, vol. 10, no. 4, pp. 25-57, 1994.

20. F. Robins. The marketing of 3G, Marketing Intelligence \& Planning, vol. 21, no. 6, pp. 370-378, 2003.

21. Heikki, Karjaluoto, et al. Factors Affecting Consumer Choice of Mobile Phones: Two Studies from Finland, Journal of Euromarketing, vol.14, no. 3, pp. 59-82, 2005.

22. H. Koski \& T. Kretschmer.New product development and firm value in mobile handset production, Industry and Innovation, pp. 1-23, 2007.

23. S. Barutçu .(2008). Consumers' Attitudes towards Mobile Marketing and Mobile Commerce in Consumer Markets. Ege Academic Review, vol. 8, no. 1, pp.15-32, 2008.

24. R.C. Basole. Visualization of interfirm relations in a converging mobile ecosystem, Journal of Information Technology, vol. 24, no. 2, pp.144-159, 2009.

25. W.D. Hoyer, R. Chandy M. Dorotic , M. Krafft, \& S.S. Singh. Consumer cocreation in new product development,Journal of Service Research, vol. 13, no. 3, pp. 283-296, 2010.

26. T. M. A. Noldus. The influence of innovation introduction rate on consumer's buying decisions,Bachelor thesis, Marketing Department, Tilburg University, 1-29, 2010.

27. C. Pelau\& P. Zegreanu (2010). Mobile marketingthe marketing for the next generation. Management \& Marketing, vol.5, no. 2, pp.101, 2010.

28. K. Watchravesringkan, N. H. Nelson \& Y. H. Kim. Exploring consumers' adoption of highly technological fashion products: The role of extrinsic and intrinsic motivational factors, Journal of Fashion Marketing and Management: An International Journal, vol. 14, no. 2,pp. 263-281, 2010.

29. S. Alessandro, D. Gray, \& L. Carter. Push-pull factors in switching mobile service providers. In Proceedings of the Australian and New Zealand marketing academy conference (pp. 1-8), 2012.

30. A.J. Rohm et. al. Brand in the hand: A crossmarket investigation of consumer acceptance of mobile marketing.Business Horizons, vol. 55,pp.485493, 2012.

31. K.P. Sinha,P. Baines, C. Fill \& K. Page, K.. MARKETING Asian Edition. New Delhi: Oxford University Press, 2015.

32. S. Hao \& M. Song. Technology-driven strategy and firm performance: Are strategic capabilities missing links?. Journal of Business Research, vol. 69, no. 2, pp. 751-759, 2016.

33. L. Liu \& Z. Jiang. Influence of technological innovation capabilities on product competitiveness. Industrial Management \& Data Systems, vol. 116, no. 5, pp. 883-902, 2016.

34. G. Wang, Jonathan and V.A. Gunawan. Success Factors Influencing Consumers' Willingness to Purchase Brand Advertised Through Mobile Phone in Indonesia, International Journal of Advanced Trends in Computer Science and Engineering, vol. 8, no.5, pp. 2581-2585, 2019.

35. R. Alnanih, N.Bahatheg, M. Alamri, \& R. Algizani . Mobile-d approach-based persona for designing user interface. International Journal of Advanced Trends in Computer Science and Engineering, vol. 8, no.5, pp. 2597-2607, 2019. 